Civil, Civility, Civilize, Civilization: Uses,

\title{
Civil, civilidade, civilizar, civilização: usos, significados e tensões nos dicionários de língua portuguesa (1562-1831)*
}

Meanings and Tensions in Dictionaries

of Portuguese (1562-1831)

Luís Filipe Silvério Lima

Professor no Departamento de História da Universidade Federal de São Paulo (EFLCH / UNIFESP Guarulhos / Brasil) e-mail: Ifslima@unifesp.br
Este texto foi gestado para as discussões do grupo "Civilização: entre dois mundos", da EFLCH/ Unifesp, e uma versão dele foi apresentada no Simpósio da ANPUH, em São Paulo (2011). Agradeço os diversos comentários e críticas recebidos nesses fóruns, nomeadamente de Bruno Feitler e Evergton Sales Souza. Também agradeço a leitura e comentários de Ana Karícia Machado Dourado, Andréa Slemian e Sérgio Alcides em versões anteriores do artigo, bem como dos editores e pareceristas da revista. Esta pesquisa é resultado parcial de projetos financiados pelo CNPq e Fapesp.

\section{Resumo}

0 artigo pretende traçar a dicionarização e usos do termo "civilização" e correlatos, identificando sinônimos e antônimos que constituíram os seus diversos significados na língua portuguesa. Para tanto, busca-se mapear o aparecimento e utilização desses vocábulos nos dicionários e vocabulários portugueses (cotejando com o trajeto em inglês, francês e espanhol), do século XVI até inícios do séc. XIX. A proposta é reconstituir os campos semânticos construídos pelos dicionários em torno da ideia de civilidade/ civilização (e seus opostos) no Império português.

\section{Abstract}

The article intends to trace the dictionarization and uses of "civilization" and related terms, identifying synonyms and antonyms which constituted their various meanings in the Portuguese language. The paper seeks to map the emergence and utilization of these words in Portuguese dictionaries (comparing with English, French and Spanish works), from mid-sixteenth century to the early nineteenth century. The main goal resides on reconstruct the semantic fields built by the dictionaries around the idea of civility / civilization (and their opposites) within the Portuguese Empire.

\section{Palavras-chave}

civilização, dicionários, rústico, Império português

Keywords

civilization, dictionaries, rustic, Portuguese Empire

DOI - http://dx.doi.org/10.1590/2236-463320120306 
BOWDEN, Brett. The ideal of civilisation: Its origins and socio-political character. Critical Review of International Social and Political Philosophy, v.7, n.1, 2004. p.26-27.

2

PAGDEN, Anthony. The 'defence of civilization' in eighteenth- century social theory. History of the Human Sciences, n.1, 1988. p.33-45; SWENSON, James. A Small Change in Terminology or a Great Leap Forward? Culture and Civilization in Revolution. MLN, vol.112, n.3, German Issue (Apr., 1997). p.322-348.

3

BOWDEN, Brett. Op. Cit.

4

DEJEAN, Joan. Antigos contra modernos: as guerras culturais e a construção de um fin de siècle. Rio de Janeiro: Civilizaçao Brasileira, 2005 [1997]; GOODY, Jack. O roubo da História: como os europeus se apropriaram das idéias e invenções do Oriente. São Paulo: Contexto, 2008 [2006], esp. cap. "0 roubo da 'civilização': Elias e a Europa absolutista"; GORDON, Daniel. The canonization of Norbert Elias in France. A Critical Perspective. French Politics, Culture \& Society, v.20, n.1, Spring 2002. p.68-94; LADURIE, Emmanuel Le Roy. Saint-Simon ou o sistema de Corte. Rio de Janeiro: Civilização Brasileira, 2004 [1997], Anexo I "Sobre Norbert Elias". No Brasil, a leitura de Elias se deu, sobretudo, a partir da década de 1990, com a tradução de suas obras pela Zahar, nomeadamente O processo civilizador, em 1990 e 93.

5

ELIAS, Norbert. Processo civilizador. $2^{\text {a }}$ ed. 2 Vols. Rio de Janeiro: Jorge Zahar Ed, 2011 [1939]; FEBVRE, Lucien. Civilisation. Évolution d'un mot et d'un groupe d'idées. In: BERR, Henri (org.). Civilisation - le mot et l'idée - Exposés par Lucien Febvre, Émile Tonnelat, Marcel Mauss, Adfredo Niceforo et Louis Weber. Paris: la Renaissance du livre, 1930. p.10-59 (versão eletrônica em: http://classiques.uqac.ca/ classiques/febvre_lucien/civilisation/civilisation. html); BENVENISTE, Émile. Civilização - contribuição à história da palavra [1954]. In: Problemas de linguística geral. $5^{\text {a }}$ ed. Campinas: Pontes Editores, 2005. p.371-381; STAROBINSKI, Jean. A palavra 'civilização'. In: As máscaras da civilização: ensaios. São Paulo: Companhia das Letras, 2001. p.11-56; MAZLICH, Bruce. Civilization and its contents. Stanford: Stanford University Press, 2004; MONNIER, Raymonde. The Concept of civilisation from Enlightenment to Revolution: An Ambiguous Transfer. Contributions to the History of Concepts, n.4, 2008, p.106-136.

6

BOER, Pim den. Towards a comparative History of Concepts: civilisation and beschaving. Contributions to the History of Concepts, n.3, 2007, p.207-233.

7

FERNANDÉZ SEBASTIÁN, Javier. The Concept of Civilization in Spain, 1754-2005: From Progress to Identity. Contributions to the History of Concepts, n.4, 2008, p.81-105.

8

DEJEAN, Joan. Op. Cit.; LADURIE, Emmanuel Le Roy. Op.Cit.; GOODY, Jack. Op. Cit.
Não pedem as palavras antiquadas, que usemos dellas, porque o discurso, como o corpo, sempre se há de vestir segundo o uso do tempo.

Raphael Bluteau, Decisoens academicas de palavras portuguezas

Nas últimas décadas, manifestou-se um interesse em repensar e investigar a história do conceito de Civilização'. Seja influenciado pela retomada reflexiva do termo nas Ciências Sociais (em contraposição ao uso de Cultura)2 ${ }^{2}$, seja motivado pelo debate em torno do "choque de civilizações"3, seja procedendo uma revisão crítica da influência marcante da obra de Norbert Elias na historiografia das décadas de 1970 e 80 (especialmente sobre a Época Moderna) ${ }^{4}$, há uma produção significativa que reequaciona a importância da trajetória da ideia de civilização para a construção ou como marco identificador/identitário dos mundos moderno e contemporâneo ocidental.

Muito tem se feito no sentido de investigar o surgimento e, mais do que isso, a popularização do termo e seus correlatos. Nessa senda, historiadores têm se dedicado a: por um lado, aprimorar e retificar a história da palavra nas línguas inglesa e francesa ( $\mathrm{e}$, por contraposição, também a alemã) traçada já na década de 1930 por autores como Lucien Febvre (1930) e Elias (1939) ${ }^{5}$; por outro, ampliar o escopo do debate analisando (comparativamente) esse processo em línguas que ficaram marginais ou ausentes nesses traçados inaugurais, como o holandês ${ }^{6}$, espanhol ${ }^{7}$, etc. Alguns desses trabalhos, inclusive, questionam a centralidade do termo como chave explicativa dos modos de comportamento e sociabilidade que teriam marcado a chamada civilização ocidental, supondo nuances nos processos de contenção, repressão e ordenação que teriam construído a racionalidade europeia ${ }^{8}$ ou nas diferenças passiveis de serem traçadas pelo uso ou não da ideia de civilização entre as diversas nações do Velho Continente. ${ }^{9}$ Outros refletiram sobre a tessitura do termo: se pensável somente para as dinâmicas de comportamento e diferenciação social internas às sociedades europeias (num momento de ascensão burguesa e redesenho das estruturas cortesãs e nobiliárquicas), como indicaria uma primeira leitura dos trabalhos de Elias e Febvre, ou se necessário ter também em vista as situações e embates nos espaços ultramarinos com os "bárbaros".10 Parte desse esforço se dá numa abordagem ligada à "História dos Conceitos", retomando e revendo o ambicioso projeto de Reinhardt Koselleck de um mapeamento do vocabulário político que significaria a construção do Estado ocidental." É parcialmente inspirado nessa abordagem que pretendo traçar uma rota por meio dessas diversas discussões que recolocam os significados da palavra em questão.

Proponho aqui fazer alguns primeiros apontamentos nessa direção relacionados aos caminhos do termo civilização e correlatos, como civilidade, civilizar, civil, rústico, bárbaro, selvagem, entre outros, identificando sinônimos e antônimos que constituíram seus diversos significados na língua portuguesa, sem perder de vista, entretanto, uma dimensão comparativa com a história mais geral do(s) termo(s). Para tanto, pretendo mapear o aparecimento e utilização desses vocábulos nos dicionários e vocabulários portugueses (cotejando com o trajeto em inglês, francês e espanhol), do século XVI (a partir de 1562, quando apareceram os primeiros repertórios lexicográficos) até inícios do séc. XIX (quando a palavra foi dicionarizada, em 1831, e houve o estabelecimento do padrão contemporâneo de dicionários). ${ }^{12} \mathrm{~A}$ ideia, menos do que buscar verificar o quanto as culturas e sociedades de língua portuguesa estavam ou não em sintonia com o de- 
BOER, Pim den. Towards a comparative History of Concepts...., Op. Cit.

10

BOWDEN, Brett Op. Cit.; PAGDEN, Anthony. Op. Cit.

11

BOER, Pim den. Towards a comparative History of Concepts..., Op. Cit.; Idem. Civilização: comparando conceitos e identidades. In: JASMIM, Marcelo. História dos conceitos: diálogos transatlânticos. São Paulo: Loyola, 2007. p.121128; FERNANDÉZ SEBASTIÁN, Javier. Op. Cit.; MONNIER, Raymonde. Op. Cit.

12

Para a periodização da história dos dicionários em língua portuguesa, baseei-me em: VERDELHO, Telmo. Dicionários portugueses, breve história. In: NUNES, José Horta; PETER, Margarida (org.). História do saber lexical e constituição de um léxico brasileiro. São Paulo: Humanitas, 2002. p.15-62.

13

A expressão "plano civilizador" foi cunhada por Serafim Leite para uma carta de Nóbrega, de 1558 LEITE, Serafim. História da Companhia de Jesus no Brasil. 3a ed. São Paulo: Loyola, 2004 [1ª Ed., 1938], t.Il, liv.Il, cap.1, p.264. Pretendo tratar desse tema em outro artigo, que está em elaboração.

14

Sobre contexto linguístico e historicidade dos termos e ideias, ver: SKINNER, Quentin. Visões da política: sobre os métodos históricos. Algés : Difel, 2005, cap. 4 e 6 .

15

Para uma lista dos dicionários portugueses ver o site do projeto "Dicionário dos Dicionários Portugueses", organizada pelo professor Dieter Messner: http://www.sbg.ac.at/rom/people/ prof/messner/dddport.htm. A partir da lista ali presente, tentei reconstituir o caminho dos termos elencados neste artigo nos dicionários lusitanos. Para tanto, além de pesquisa em bibliotecas "presenciais", utilizei-me dos documentos disponibilizados em bibliotecas virtuais, como Brasiliana Digital (http://www. brasiliana.usp.br/dicionario), Biblioteca Nacional Digital (http://purl.pt/index/geral/PT/index.html) e Google Books (http://books.google.com/), entre outras. Para complementar a pesquisa, também me utilizei de bases e corpus lexicográficos de português disponíveis na rede que permitiam busca por termos, muitas vezes retornando entradas de dicionários e vocabulários. Para a língua portuguesa, consultei, sobretudo, as seguintes bases: Tycho Brahe (http://www. tycho.iel.unicamp.br/ tycho/corpus/index.html acesso em 15/7/2010); Corpus Lexicográfico do Português (http://clp.dlc.ua.pt/Inicio.aspx, acesso em 21/7/2010); Corpus do Português (http://www.corpusdoportugues.org/, acesso em 23/7/2010). Como indicado nesta e em outras notas, bem como nas referências, a pesquisa para este artigo teria sido muito mais restrita se não fosse o acesso e a disponibilização de recursos como esses na internet. Para um comentário sobre o uso das bases de dados lexicográficas e de dicionários on-line e seu impacto na pesquisa histórica, ver: DEJEAN, Joan. Op. Cit., Prefácio. senvolvimento das "civilizações" francesa e inglesa, é identificar os campos semânticos construídos pelos dicionários em torno da ideia de civilidade/ civilização (e seus opostos).

Dentro dos seus limites "lexicográficos", esta primeira aproximação pretende, assim, servir como subsídio inicial para reflexões posteriores e mais precisas sobre como os termos civilização, civilidade, civilizar, etc. foram ou não empregados (e como o foram) ao longo da colonização portuguesa em seus domínios ultramarinos. Em um momento futuro, seria particularmente importante abordar essa questão ao se pensar a conversão dos índios e o projeto missionário lusitano na América, entendido, por muitos, como dentro de um "plano civilizador" já desde os quinhentos. ${ }^{13}$

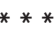

Os dicionários não devem ser lidos simplesmente como "retratos da língua". Não refletem o uso tal e qual do emprego vocabular nem, até o séc. XVIII, pautavam exclusivamente a norma da língua, esta mesma muito fluida. Representam repertórios elegidos que obedeciam critérios muitas vezes não "lexicográficos" - e como tal podem nos dar pistas para pensar os conceitos em seu contexto linguístico e em sua historicidade. ${ }^{14}$ Nos séc. XVI e XVII os dicionários serviam como um instrumento, ao mesmo tempo, de afirmação da importância e variedade do vernáculo no concerto dos reinos, e também de erudição para uso dos letrados, especialmente no caso português, já que eram dicionários latim-português.

Tendo isso em vista, o que pretendo traçar aqui nesta primeira parte do texto é como nos dicionários da segunda metade do século XVI a primeira do XVIII apareceram as conversões entre os termos latinos civilis, civilitas, civiliter etc e seus correlatos para o português. 0 que interessa notar é que há uma plasticidade semântica, que mostra a adaptação do léxico latino - tido como organizador e referência - aos campos semânticos construídos na Época Moderna, pelos quais civil e civilidade se tornam, por vezes e, para nós, paradoxalmente, 0 antônimo da acepção contemporânea (e, em certa medida, latina). Essa plasticidade, também reflexo de uma prática linguistica sem tantas normas fixas, acaba por gerar ambiguidades na comparação das diferentes entradas dos diversos dicionários da primeira modernidade - e, por isso, pode fazer o leitor contemporâneo perder-se na selva lexical. A intenção deste primeiro item é passear por esse emaranhado, destrinchando-o, e mapeando as variadas nuances que podem ser reflexo, ao mesmo tempo, do deslizamento do termo e/ou da falta de fixidez das definições e práticas lexicográficas. Interessa perceber como, apesar de se manter a referência ao latim, houve, paulatinamente, um distanciamento do sentido de civil e variantes para com seus homólogos latinos, que, se não culmina, explicita-se com as entradas explicativas no Vocabulário Latino-Português (1712-1728) de Raphael Bluteau. Ali definiu-se "civil" e "civilidade" como opostos ao sentido latino, trazendo para o campo da "civilitas" termos ligados não somente à vida citadina mas (e sobretudo) à cortesã. Porém, esse sentido, apesar de diminuir - ou mesmo desaparecer nos léxicos após Bluteau (o que será visto no item seguinte), não começou com ele. Por isso, vale a pena recuar ao século XVI.

Alguns dos primeiros repertórios lexicográficos ${ }^{15}$ existentes para 0 português foram os produzidos pelo jesuíta Jerônimo Cardoso. Em 1562, saiu impresso o seu Dictionarium ex Lusitanico in latinum sermonem, 
16

Utilizei-me sobretudo da edição de 1569-1570 (terminada em 1569, mas divulgada em 1570, data pela qual será referida), da qual pude consultar tanto o dicionário latim-português como o português-latim. Cotejei com a edição de 1562, português-latim, e uma das últimas impressões, em 1694 (a nona a partir da edição de 1569-70). A pesquisa e as citações foram feitas a partir das versões digitalizadas disponiveis na Biblioteca Nacional Digital (BND), da Biblioteca Nacional de Portugal: http://purl.pt/ index/geral/PT/index.html.

17

VERDELHO, Telmo. Dicionários portugueses, breve história..., Op. Cit., p.17-19.

18

CARDOSO, Jerônimo. Dictionarivm latino Ivsitanicvm \& vice versa Lusitanico latinum. [Coimbra]: Ion. Barrerius, 1570, f.37v. [Versão on-line disponivel na Biblioteca Nacional Digital: http://purl.pt/14265 - acesso em 25/5/2010].

19

Ibidem, f.27, 29, 185 e $269 v$. vertendo os vocábulos portugueses para seus correspondentes latinos, e, em 1570, postumamente, o Dictionarium latino lusitanicum que trazia também a tradução do latim para o português. A versão de 1570, até finais do séc. XVII, teve mais de uma dezena de edições que pouco diferiam entre $\mathrm{si}^{16}$ e participava de um esforço de codificar e criar um repertório das línguas vernáculas que se observa nos reinos europeus ao longo dos séc. XVI e XVII. Consistia, assim, menos em um dicionário monolíngue de significados dados em português, e mais numa compilação do vocabulário em português e sua tradução para o latim, e vice-versa. Um modelo que foi predominante no séc. XVI nos círculos humanistas da Europa marcados pela autoridade do latim como matriz gramatical, retórica e poética e que, para a língua portuguesa, manteve-se até inícios do séc. XVIII. ${ }^{17}$

Entre as entradas não podia constar a palavra civilização, "neologismo" do século XVIII, mas apareciam vocábulos que remetiam ao latino civitas (cidade). Do latim para o português, "Ciuiliter" era traduzido como "cortesmente", "ciuilis", como "cousa da cidade, ou cortes", "ciuicus", "cousa de cidadão"18. Ao fazer o caminho inverso, português-latim, "ciuil cousa" aparecia vertido para "ciuiles"; "ciuilmente", "ciuiliter", e "cidadão ou cidadã" como "civis" e "cidade", "civitas".

Fugindo do radical "civi" e distanciando-se da transposição direta latim-português, "cousa de cidade" era vertido para "vrbicus, a, am" ou "vrbanus". A tradução de "Vrbanus", "vrbanitas" e "vrbaniter" não remetia à cidade, civil ou civilmente em português, mas, respectivamente, a "cortes", "cortesia" e "cortesmente", enquanto "Vrbs" era "cidade". Era "politicus, a, um", em latim, que remetia ao lusitânico "cousa da cidade". Por sua vez, o atributo cortês ("cortes cousa") e derivados congregavam todas as correspondências de civil e urbano: "cortesmente" podia ser vertido para "civiliter, comiter"; "cortesia" para "vrbanitas"; "cortesaãmente", "Aulice, ciuiliter"; "cortesão", "aulicus, a, um"; e finalmente "cortes cousa", que podia ser "vrbanus, a, um, comis, Ct e, ciuilis, Ct, e". Ser cortês (um adjetivo) diferenciava-se de cortesão (um substantivo), ainda que "cortesaãmente" reunisse tanto o atributo de cortesão ("Aulice") quanto de cortês ("ciuiliter"). ${ }^{19}$

Menos do que aquele pertencente à corte (o cortesão), cortês era 0 atributo de quem tinha urbanidade (cortesia), agia civilmente (cortesmente), localizando-o no ambiente urbano, entendido aqui talvez mais como o local da civitas metafórica, da res publica, do que o das cidades e vilas lusitanas concretas do séc. XVI. Traçava-se um campo semântico comum, ligado à cidade, à urbes. Entretanto, havia nuances entre os termos, que se sobrepunham ou distanciavam conforme o uso e as tentativas de tradução entre latim e português. Revelava-se uma gama de significações que poderiam, talvez, apontar para uma necessidade de dar conta de qualificar as partes de um tecido social composto tanto do espaço urbano quanto do político, contidos ambos na "civitas" ou nas "cousas da cidade". Nesse vocabulário formado entre o Urbano, o Civil e o Cortês, o espaço republicano e citadino era próximo ao lugar de corte, pois afinal a corte, como sede ou cabeça do reino (pois lugar onde estava o rei), era, por metonimia, a parte preponderante que subsumia o corpo geral do reino, da coisa pública. Ser cortês era assim ser citadino, em um duplo significado, ser da cidade e da corte, como condensação dos atributos do reino.

Nos dicionários de Cardoso, não aparecia ao que se contrapunha o atributo cortês. Nos vocabulários que Ihe seguiram no século XVII, o Dictionarium Lusitanico Latinum de Agostinho Barbosa (1611) e particularmente 
20

BARBOSA, Agostinho. Dictionarium Lusitanico Latinum. Bracharae [Braga]: typis, \& expensis Fructuosi Laurentij de Basto, 1611. p.308 [Versão on-line disponivel na Biblioteca Nacional Digital http://purl.pt/14016/1/index.html - acesso em 21/7/2010]; PEREYRA, Benito. Thesouro da Lingua Portuguesa (...) Tem tidos os vocábulos portugueses que trazem Cardoso, \&t Barbosa, \&t de novo outros muytos mil, em tanta copia, que só os vocábulos acrecentados são outros tantos, \&t mais, que todos quantos tem os sobreditos vocabularios. (...) Em Lisboa: Com todas as licenças necessárias na officina de Paulo Craesbeeck, \& às duas custas. Anno 1647. f.33v)

21

BARBOSA, Agostinho. 0p. Cit., p.309, grifos meus.

22

PEREYRA, Benito. Op. Cit., f.33v, 76 ss. o Thesouro da Lingoa Portuguesa do jesuíta Bento Pereira (1647), delineava-se, por meios indiretos, o antônimo preferencial dos termos latinos civilis e civiliter: rusticus e rustice. Rústico e rusticamente (traduzidos para o português) eram os atributos de quem vivia no campo, construindo assim uma antinomia entre o citadino ou cidadão cortês e o campônes rústico.

Nesse sentido, poderíamos assumir que os antônimos de civil e civilmente fossem rústico e rusticamente. Entretanto, se "cousa civil" e "civilmente" aparecem sim como "civilis" e "civiliter"20, tal qual no dicionário de Jerônimo Cardoso, ambos acrescentaram, logo em seguida, uma outra acepção: a de "rusticus" e "rusticè". Isto é, os vocábulos derivados de civil assumem significado contrário à sua acepção latina. Civil é o rústico. Ou como aparece no dicionário português-latim de Barbosa: "cousa ciuil, aliàs rustica. Rusticus, a, um" ou "ciuilmente, i. como rustico. Rusticè"21. Acrescentou ainda mais uma entrada (que não existia em Cardoso), o vocábulo "ciuilidade" que vertia somente para "Rusticitas" ou "rusticitatis", sem qualquer remissão ao sentido citadino ou cortesão do termo. No Thesouro da Lingoa Portuguesa, que integrava um esforço pedagógico e lexicográfico dos jesuítas de Évora, ampliaram-se as possibilidades de significados correlatos, não só pelo maior número de sinônimos latinos, mas também porque continha mais vocábulos, já que desde o título anunciava pretender superar, por muito, os vocábulos reunidos por Cardoso e Barbosa.

De um lado, "Civil cousa" seria o correspondente aos termos latinos também "civilis" e, aqui uma acepção nova e importante, "politicus". "Politica cousa", por sua vez, seria o latino "politicus", enquanto "politicamente" viraria "civiliter, urbanè". Na mesma página, aparecia "policia", vertido para "civilitas" (que não seria civilidade em português, pois esta significaria o exato oposto, rusticidade) e também para "urbanitas, atis" e "Elegantia". "Eleganter", advérbio derivado de "Elegantia", definia "polidamente", também concebido como "Politè. Ornati", aproximando agir de modo polido (elegante) e de modo político ou com polícia (urbanidade). ${ }^{22}$ As coisas civis (por que não republicanas, da res publica) eram políticas, urbanas (remetendo à cidade, à civilidade) mas também polidas, elegantes, ornadas (remetendo à etiqueta e ao refinamento da corte), identificando a polícia com a polidez.

Por outro, "Civel cousa" viraria "sordidus" e "rusticus". Uma "Rustica cousa" é "Agrestis" e "Rusticus", mas o interessante é que "Rusticamente" se verte também para "inurbané" e "Rusticidade", para "Inciuilitatis". Para além de ser do campo (agreste), age como rústico aquele que tem incivilidade e se porta "inurbanamente". Sinônimos de "rusticus" em português estariam nas entradas "Barbara Cousa" e "Villã cousa", respectivamente vertidas para "Barbarus (...). Rusticus" e "Rusticus (...) villicus". As entradas ligadas a "villã cousa" chamam atenção. Após a primeira entrada "Villã cousa" segue outra que adenda "Villã cousa, i. descortez" vertendo para o latino "Inciuilis". Por sua vez, "Villãmente" seria "Rusticè, inciviliter". Vilão era aquele ou aquilo que vivia no campo (rústico) mas também o descortês e incivil. Mais do que isso, se não havia uma entrada para o substantivo rústico (só para o adjetivo rústico, "Rustica cousa"), aparece uma para o nome "Villão", vertido pura e simplesmente para "Rusticus"23. 0 vilão era a personificação do rústico, caracterizado também como descortês e incivil. Entretanto, o termo civil qualificaria, paradoxalmente, as coisas rústicas.

Para o castelhano, desde o século XVI, era notada esta ambiguidade e destacada a duplicidade do uso "civil" no âmbito dos círculos humanistas 
VALDÉS, Juan de. Dialogo de la lengua. Madrid: Impr. de J. Martin Alegría, 1860 [c. 1533]. p.198.

25

Apud. BATAILLON, Marcel. Erasmo y España. México: FCE, 1996. p.119.

26

ELIAS, Norbert. Processo civilizador. Rio de Janeiro: Jorge Zahar Ed, 1993, cap.1, pte.2; cf. BOER, Pim den. Towards a comparative History of Concepts..., Op. Cit.

27

BATAILLON, Marcel. Op. Cit., p.LIV. Ao contrário, por exemplo, do que ocorrera na Inglaterra, na Alemanha e na Holanda, onde houve várias traduções. Nessas edições, o termo latino civilitate do título, entretanto, não foi traduzido para seus derivados nos vernáculos mas por termos próximos a boas maneiras/ modos ou cortesania (BOER, Pim den. Towards a comparative History of Concepts... Op. Cit., p.217-219). A obra sofreu uma "tradução-plágio" em espanhol na forma de um capitulo de uma obra maior, El estudioso de la aldea, de Palmerino de 1568, que se intitulava "Tratado de la buena crianza en el niño del Aldea". A não remissão a Erasmo faz sentido por ser obra de influência erasmista, num momento que recrudescia a perseguição aos erasmistas na península Ibérica. Contudo, talvez seguindo as outras traduções, não houve também menção à "civilidad" ou tradução correspondente ao "civilitate" (cf. GALLEGO, André. Un avatar espagnol du De civilitate d'Erasme. Le Tratado de la buena criança de I'humaniste aragonais J.L. Palmireno. In: DUROUX, Rose (org.). Les traités de savoir-vivre en Espagne et au Portugal du Moyen Age à nos jours. Clermont-Ferrand (França): Université Blaise Pascal, 1995. p.106-120.)

28

COVARRUBIAS OROZCO, Sebastián de. Tesoro de la lengua castellana, o española. Madrid: Por Luis Sanchez, impressor del Rey N.S., 1611. f.288 [versão digital consultada em Fondos Digitales da biblioteca da Universidade de Sevilha: http://fondosdigitales. us.es/fondos/libros/765/614/tesoro-de-la-lenguacastellana-o-espanola/, em 31/7/2010].

29

Cf. VERDELHO, Telmo. Dicionários portugueses, breve história..., Op. Cit.

30

SILVESTRE, João Paulo. 0 Vocabulario Portuguez, e Latino: principais características da obra lexicográfica de Rafael Bluteau. Comunicação apresentada no encontro Dicionários da Língua Portuguesa - Património e renovação, Cursos da Arrábida, 20 de Julho a 2 de Agosto de 2001, Portugal, p.2-3, [Texto on-line em Corpus Lexicográfico do Português, consultado em 20/07/2010: http://clp.dlc.ua.pt/Publicacoes/ vocabulario_principais_caracteristicas.pdf]. espanhóis, preocupados, entre outras coisas, com a precisão e definição dos termos. Em Dialogo de la Lengua, manuscrito redigido por volta de 1533, Juan de Valdés escreveu que em espanhol: "Usamos tambien civil, en contraria sinificazion, que lo usa el Latin, diziendo en un refran, caséme con la zevil, por el florin: adondo zevil esta por vil, i baja".24 Mais ou menos a mesma altura, a diferença é notada por Diego Lopez Zuñiga em uma carta por conta de uma disputa com Erasmo (citado também como um dos interlocutores do diálogo de Valdés): "Y cuanto a lo que toca a la Apologia del señor Erasmo, si yo no me engaño, él me respondió 'satis civiliter' no como él entendió, sino según suena en buen romance castellano." ${ }^{25}$. Interessante notar que foi uma obra de Erasmo, De civilitate morum puerilium, de 1530 que, segundo Elias ${ }^{26}$, teria sido um dos marcos iniciais do processo civilizador e da própria gestação da ideia de civilidade na Europa Moderna. Obra esta que teve pelo menos três edições do texto em latim na Espanha quinhentista, ainda que não tenha sido traduzida para um idioma espanhol, fazendo assim circular o termo latino para civilidade na acepção de bons modos. ${ }^{27}$

Havia no mundo ibérico, portanto, uma tensão semântica em torno dos termos civil, civilidade, que ora representavam atributos baixos, mundanos, dos vilões e rústicos (e que, curiosamente, era dito como de uso mais corriqueiro, no "romance" vulgar, civil talvez), ora ao exato oposto, remetendo à origem latina e significando aquilo que é relativo tanto à corte e à polidez quanto ao urbano e político (e que ressoava assim um sentido mais afeito ao meio europeu humanista). Ambiguidade que podia resultar em problemas de tradução e compreensão dos vernáculos das Espanhas, como notaram esses letrados castelhanos quinhentistas, mas que, curiosamente, não foi anotada pelo extenso e abrangente Tesoro de la lengua española, de Covarrubias. Em Covarrubias, não constava entrada para civilidade, e civil sequer merecera um verbete à parte, aparecendo quase que uma derivação de "civdadano" (o habitante da cidade) ligado a tudo que se refere ao direito da cidade, entendida também como sinônimo de república, i.e., "multitud de hombres ciudadanos, que se há congregado a vivir em un mesmo lugar, debaxo de unas leyes y un govierno"28.

No Vocabulário, escrito pelo teatino Raphael Bluteau, explicitava-se essa contradição para o português um século mais tarde. Primeiro dicionário que trazia explicações dos significados dos termos e vários sinônimos em português, além da correspondência - indicada desde o título - em latim (tal qual seus predecessores), o Vocabulário ficava no meio do caminho entre os repertórios latim-português dos séculos XVI e XVII e um dicionário monolíngue nos termos mais contemporâneos. ${ }^{29}$ Por isso e pela sua dimensão monumental (8 volumes in-folio, 2 tomos de suplemento, perfazendo mais de 7.000 páginas, diferindo da economia dos repertórios lexicográficos anteriores), a obra de Bluteau tornou-se referência para os letrados eruditos do período e ponto de partida para os dicionários que 0 seguiram. Foi esse teatino inglês de família francesa, educado e ordenado em Paris, mas radicado em Lisboa desde 1668, quando aprendera a língua portuguesa depois dos 30 anos, que obteve apoio da coroa para realizar um tal dicionário que suplantasse qualquer outro de qualquer reino europeu. ${ }^{30}$ Bluteau fazia parte dos círculos das academias lusitanas que se formavam desde finais do séc. XVII, e, nas discussões acadêmicas, manifestava-se a preocupação com o estabelecimento da língua portuguesa. 0 padre e letrado conduziu e participou desses debates sobre gramática, retórica, ortografia, etimologia, ao mesmo tempo que elaborava o plano do Vocabulário. 
31

BLUTEAU, Rafael. Prosas portuguezas recitadas em differentes congressos academicos... Lisboa Occidental: Na Officina de Joseph Antonio da Sylva, 1729 [2 partes em 1 volume].

32

BLUTEAU, Rafael. Vocabulario Portuguez e Latino. Coimbra: No Collegio das Artes da Companhia de Jesu, 1712-1728, Vol.2, p.322-3 [versão online consultada na Brasiliana Digital: http://www. brasiliana.usp.br/dicionario - em 21/5/2010]

33

Não pude consultar esta obra, mas ela fazia parte de um volume de poesias do autor, que, ao que parece, já era raro no século XIX. Cf. COSTA E SILVA, José María da. Ensaio biographico-critico sobre os melhores poetas portuguezes. Lisboa: Imprensa Silviana, 1834, t.VII, p.41.

34

STAROBINSKI, Jean. A palavra 'civilização'. In: As máscaras da civilização: ensaios. São Paulo: Companhia das Letras, 2001. p.19-21.
Nessas tertúlias e sessões, proferiu inúmeras orações, discursos e relatou discussões, depois reunidas nas suas Prosas portuguesas, como as "Decisoens academicas de palavras portuguezas", de 1696, da qual retirei a epígrafe deste texto. ${ }^{31}$ Essa preocupação com a língua portuguesa era traduzida nos verbetes do Vocabulário na busca por repertoriar os diversos sentidos e possiveis etimologias, no suporte por abonações constantes, nos comentários que, por vezes, ganhavam caráter quase "enciclopédico". Isso se vê, em certa medida, nos verbetes "Civil" e "Civilidade", transcritos parcialmente abaixo:

CIVIL. Cousa concernente a Cidadaõs, à Sociedade, \&t vida humana. Civilis, le, is. (...) Civil. Às vezes pôr antiphrasis se toma por Descortez grosseiro, rustico \&c. Como a gente ba[i]xa, de sua natureza he, Civil, \&t inclinada a mal. Chron. Del Rey D. João I. fol. 19 col. 2 Por serem estes homens muyto Cives, \&t que elle, por outros delitos, \&tc. Barros Dec. 3. fol. 217 col I.

CIVILIDADE. Descortezia, Grosseria, Rusticidade. Parece derivado do Latim Civilitas, mas em sentido contrario, \&t por Antiphrasis, como Bellum, quia minimè bellum: \&t assi Civilidade, \& Civel em Portuguez he contraditorio de Civilitas, \& de Civilis no Latim. V. Descortezia, Grosseria, \&c. Civilidade, parece, que possa dizer hum homem de bem. ${ }^{32}$

Na entrada "Civilidade", o termo constava como "descortezia, grosseria, rusticidade", muito próximo à segunda definição de civil dada por Bluteau, que, por antífrase, "se tóma por Descortez, grosseiro, rustico \&cc.", dando como abonações dois trechos de crônicas, uma de Fernão Lopes, outra de João de Barros, exemplos máximos entre os historiógrafos portugueses. No verbete "Civilidade", por sua vez, Bluteau mandava ver "Rustico, Camponez, Agreste". Acepções que seriam, segundo o próprio Bluteau, contrárias aos vocábulos latinos dos quais derivavam (civilitas e civilis), do mesmo modo que belo em relação a bellum (guerra em latim). Mais, que seriam mesmo contraditórias com o primeiro sentido do termo português "civil" (mais próximo à sua origem latina) que exprimia "as coisas concernentes a Cidadãos [aquele que mora na cidade], à Sociedade \&t vida humana". Bluteau ainda permitiu, no fim do verberte, que houvesse um uso positivo, dizendo que "Civilidade, parece, que se possa dizer hum homem de bem", remetendo a um texto de Francisco de Portugal, Prisão e soltura da alma, impresso postumamente em $1652 .{ }^{33}$

Ainda que associemos, atualmente, "civilidade" e "civil" a ser civilizado e polido (como presente atualmente na sexta definição de civil no dicionário Houaiss), a acepção dicionarizada até inícios do século XVIII não era exclusivamente essa. Podia ser também próxima a de descortesia - 0 que indicava o caráter não cortesão, pouco "político" (polido e civil, ao mesmo tempo) do povo, dos que não eram fidalgos -, e de vilania e rusticidade - o que apontava para o aspecto camponês, dos rústicos (ou vilões) que viviam próximos à natureza, e, portanto, dir-se-ia mais tarde, não civilizados. Parafraseando Bluteau, qualificariam a natureza da gente baixa de inclinação para o mal. É interessante notar que, seguindo a definição do Vocabulário, civilidade estava ligado à rusticidade, quando, em Roma, como nota Starobinski ${ }^{34}$, rusticitas era o oposto complementar de urbanitas (e próximo a ela, civilitas) - tal qual na Grécia, bárbaro seria inseparável do seu antônimo, grego. Assim, mesmo que "civil" pudesse significar, aderente à sua raiz latina, coisas referentes à cidade, "civilidade" e outra acepção de "civil" diziam respeito ao mundo do campo (rústico) e ao mundo fora da 
35

BLUTEAU, Rafael. Vocabulário..., 0p. Cit., 17121728, Vol.8, p.492.

36

É interessante notar que o Dicionário PortuguezLatino de Folqman, impresso em 1755, que se pretendia uma versão resumida de Bluteau útil para o estudo de latim e português, só apresentava o verbete "Civil" (traduzido como Civilis), não constando nem civilidade, nem civilizar, etc (FOLOMAN, Carlos. Diccionario Portuguez, e Latino. Lisboa: Na Officina de Miguel Menescal da Costa, 1755. p.119). Também vale frisar que, no Elucidário de Viterbo, que se pretendia um dicionário de termos antigos e em desuso, não aparece nenhuma entrada ligada a essa raiz (VITERBO, Joaquim de Santa Rosa de. Elucidario das palavras, termos, e frases, que em Portugal antiguamente se usárão, e que hoje regularmente se ignorão. Lisboa: Na Officina de Simão Thadeu Ferreira, 1798, Vol.1). De outra parte, não aparece o termo "civilizar" (ou "civil") e seus correspondentes na língua brasiliana (tupi) no Diccionário Português-Brasiliano, de 1795 (de possivel autoria de Frei Mariano da Conceição Veloso), mas aparece "rústico" traduzido para "caapora" (disponivel na Brasiliana, http:// brasiliana.usp.br - consultado em 1/10/2011).

37

VERDELHO, Telmo. 0 dicionário de Morais Silva e o início da lexicografia moderna. In: História da língua e história da gramática - actas do encontro. Braga: Universidade do Minho/ILCH, 2003. p.473-490

38

MORAIS SILVA, António de. Diccionario do lingua portugueza composto pelo padre $D$. Rafael Bluteau, reformado, e accrescentado por Antonio de Moraes Silva natural do Rio de Janeiro. Lisboa: Na Officina de Simão Thaddeo Ferreira, 1789, Vol.1, p.402, [versão online consultada na Brasiliana Digital: http://www.brasiliana.usp.br/ dicionario - em 21/5/2010].

39

SOUSA, Antonio Caetano de. História genealógica da casa real portugueza... Lisboa Occidental : Na Off. de Joseph Antonio da Sylva, 1739, Vol.6, p.318.

40

Directorio, que se deve observar nas povoaçoens dos indios do Pará, e Maranhão: em quanto Sua Magestade naõ mandar o contrario. Lisboa: Officina Miguel Rodrigues, 1758. p.3-4, 6, 10-1, 16,37 , pass.

41

MORAIS SILVA, António de. Diccionario da lingua portugueza composto pelo padre $D$. Rafael Bluteau..., Op. Cit., vol.2, p.649, 650. Para uma discussão do que seria o rústico em termos legais e jurídicos, ver capítulo dedicado à categoria em: HESPANHA, António Manuel. Imbecillitas. As bem-aventuranças da inferioridade nas sociedades de Antigo Regime. São Paulo: Annablume, 2010 corte (descortez), i.e., fora dos limites da cidade política e polida. "Incivil", em suma, como o próprio Bluteau classificou, contraditório ao primeiro significado, era o "villão ruim": "Homem rústico, incivil"

Esse campo semântico mudou ao longo do século XVIII. Impresso em Lisboa no ano da eclosão da Revolução Francesa, o Diccionário da lingua portugueza de Antonio de Morais Silva apontava que a acepção presente no Bluteau (e nos vocabulários latim-português anteriores) não fazia mais sentido no final do séc. XVIII. ${ }^{36} 0$ Dicionário de Morais propunha-se como uma atualização do Vocabulário, lançado seis décadas antes, como expresso em seu título integral: Diccionario da lingua portugueza composto pelo padre D. Rafael Bluteau, reformado, e accrescentado por Antonio de Moraes Silva natural do Rio de Janeiro. Entretanto, significou a inauguração de um novo padrão de dicionário, monolíngues, com verbetes mais condensados e lançando mão de abreviaturas, seguido, em grande parte, até hoje. ${ }^{37}$

Morais sintetizava e explicitava as implicações sociais do verbete "civilidáde" de Bluteau, indicando-o como acepção arcaica e antiga, para então emendar o significado utilizado à época: "CIVILIDADE, s.f. antiq. Acção de homem do povo, de mecanino (...) 'soffrer civilidades', i.é, villanias. § Civilidade hoje significa, cortezia, urbanidade, opp. a rusticidade, grosseria." ${ }^{38}$. Em resumo, num intervalo de 60, 70 anos, segundo Morais, ter-se-ia eliminado em português qualquer ambiguidade no uso do termo "civilidade", ficando próximo no fim do séc. XVIII ao sentido utilizado nos dias de hoje.

De certa maneira, isso refletia o uso de civilidade em alguns textos portugueses já na primeira metade do séc. XVIII, como no sexto volume da Historia Genealogica da Casa Real Portugueza ${ }^{39}$. Redigida por António Caetano de Sousa e impressa entre 1739 e 1748, era obra bastante conhecida e muito referida à época, inclusive por gramáticos e dicionaristas. Civilidade também aparecia em textos legais, gerados e impressos pela Coroa, como no Diretório dos Índios, de 1758. 0 Diretório definia a atuação do poder civil sobre os nativos do Maranhão e Pará (após a saída dos jesuitas) que devia complementar a ação religiosa de cristianizá-los, agindo para "a civilidade dos índios", por meio da "educação pública", do ensino da língua portuguesa, dos "bons costumes", das "Leys da honestidade, e da policia" (e da "liberdade do commercio"!), que os ajudaria a serem polidos, decentes e os tiraria do estado de "incivil rusticidade" que atrapalhava não só sua conversão mas também os negócios do reino na região. ${ }^{40}$

Se formos, porém, olhar as acepções de rusticidade em Morais, ainda não estava incorporada completamente a antinomia com civilidade, indicada no verbete atualizado em relação a Bluteau (e presente de modo explícito no Diretório). Rusticidade é definido pelos seus opostos ("RUSTICIDADE, s.f. Opposto a urbanidade, policia, cortezania") e rústico, como camponês, mas caracterizado em seguida pela negação das quase mesmas qualidades ("Inurbano, descortez") ${ }^{41}$. Ainda que enunciado civilidade como o oposto a rusticidade no verbete renovado de Morais, rústico e rusticidade eram definidas pelos vocábulos de acepção antiga ligados aos campos semântico da cortesia, urbanidade.

Mais do que isso, havia resquícios da ideia de civil como algo de baixa condição. Tentava-se distinguir "civilidade" de "civeldade", no qual civeldade seria uma "acção vil" e indigna. Contudo, entre "civíl" e "cível", 
Novo diccionario da lingua portugueza: composto sobre os que até o presente se tem dader ao prelo, e accrescentadode varios vocabulos extrahidos dos classicos antigos, e dos modernos de melhor nota, que se achaõ universalmente recebidos. Lisboa: Typografia Rollandiana, 1806, s.p. [versão online consultada em GoogleBooks: http://books. google.com.br/books?id=ubQGAAAAQAAJctdq=no vo+dicionario+de+lingua+portuguesa+1806cthl= pt-bretsource=gbs_navlinks_s - em 24/1/2011]

44

MORAIS SILVA, Antonio de. Diccionario da Lingua Portugueza, composto por Antonio de Moraes Silva. 4a edição. Lisboa: Imp.Regia, 1831, Vol.1, p.395.

45

MORAIS SILVA, António de. Diccionario da lingua portugueza composto pelo padre D. Rafael Bluteau..., Op. Cit., vol.1, p.481, vol.2, p.464, 823.

46

Ibidem, Vol.2, p.526. a distinção era mais tênue, tal qual a entonação. Civil era, historicamente e como primeiro significado, relativo à gente que morava na cidade, "no sentido de cível" (como consta no início da entrada), epíteto dos "mecânicos, que moravão em cidades cercadas, e não nos campos, em castellos, como a gente nobre e guerreira, alias villões". Porém se "civil" encaminhava, na segunda acepção, para aquele ou aquilo "Que pertence à Cidade, ou sociedade de homens, que vivem debaixo de certas Leis" que constituem 0 Direito Civil - e se opõem ao Canônico, que rege as coisas do espírito - e "dirigem as acções do homem em quanto cidadão, ou membro do Estado Secular, e regulado pelo Soberano", terminando, no sétimo sentido, com a expressão "Homem civil; urbano, cortez: e assim modo, maneiras civis, \&tcc."; o verbete "Cível" ia por outra direção. Se naquele referia-se à "cível" logo no início, não se mencionava em nenhum momento uma relação próxima a "cívil" neste. Cível era sim atributo dos mecânicos, mas mais diretamente era o "opposto à Corte"; gente civel era "não cortezã", "não nobre, vil". "Gente vil, de más manhas", i.e., sem qualidade, sem aptidão. ${ }^{42}$ Só ao fim, a menção ao aspecto jurídico, para diferenciar uma ação cível de uma criminal, tal qual hoje, mas sem se referir a nenhum aspecto do sentido urbano (e de civilidade) mais amplo de "cívil". Distinções que estariam presentes ainda em dicionários do início do séc. XIX, como no Novo diccionario da língua portugueza, de $1806^{43}$, e que se manteriam pelo menos até a quarta edição do Morais. ${ }^{44}$

"Cívil" significava no início uma divisão social entre os citadinos (que moravam em cidades, vilas: gente civil/cível ou vilões) dos nobres (mas também dos camponeses); depois abarcou tudo aquilo referente à cidade, entendida, reforçando a origem latina, como espaço público regido por leis e por consequência a república (o Estado). As pessoas que vivessem sob a polícia desse regime civil tornavam-se pessoas de modos, de boas maneiras, civis e com civilidade. Urbanos e corteses. Contudo, "civel" restringiuse a marca negativa dada na distinção social, pela qual a "gente cível" (ou seja, o povo, a arraia miúda, seja na cidade seja no campo) não podia ter hábitos nem urbanos nem corteses. Encaixavam-se no que definia tanto rústico como rusticidade, ou seja, a ausência de urbanidade, cortesia e polícia, qualidades que misturavam, ao mesmo tempo, a vida em cidade e os hábitos de corte, os bons modos e o governo de si (ajudado pelas leis e pelo Estado). ${ }^{45}$ Qualidades condensadas na ideia de civilidade, mas que carregava ainda na raiz uma ambiguidade que a jogava para o campo semântico oposto pretendido. Era como se tentassem indicar na superposição dos verbetes que a civilidade não era para todos os civis, não era para todos que habitassem a cidade política, mas somente aos da corte dessa cidade.

Essa dimensão negativa de civil também se explicita na entrada "Villão" - termo que fora antes remetido, entretanto, pelo mais positivo verbete "civil". 0 vocábulo é definido como adjetivo daquele "que mora em villa, camponez. § Homem cível, não nobre" dando como abonação as Miscelâneas de Resende. Completava a definição os exemplos do cavaleiro definido como "villão", pois não era de linhagem, bem como servir de sinônimo aos adjetivos rústico e descortês, existindo a expressão "acção villãa" e "villão feito". Mais fortemente, era também "Homem baixo injuriosamente" ${ }^{46}$. Vilão era tanto o que morava em vila (povoação intermédia entre a cidade e a aldeia) quanto qualificava o camponês, mas também servia para designar qualquer um que não fosse nobre e, portanto, baixo, vil. 0 adjetivo, aliado à cível, qualificava as ações e a condição do homem 
47

Ibidem, Vol.2, p.526, grifos meus.

48

BACELLAR, Bernardo de Lima e Melo.

Diccionario de lingua portugueza em que se acharão dobradas palavras do que traz Bluteau, e todos os mais Diccionaristas juntos: a suá propria significação: as raizes de todas ellas: a accentuação: e a selecção das mais usadas, e polídas: a Grammatica Philosophica, e a Orthographia Racional no principio, e as explicaçoens das abbreviaturas no fim defla Obra. Lisboa: Na Offic. De Jozé de Aquino Bulhoens, 1783. p.107-108 [Versão on-line disponivel no Google Books em: http://books.google.com.br/bo oks? $\mathrm{id}=55 \mathrm{ICAAAAQAAJCtprintsec}=$ frontcover $\# \mathrm{v}=$ onepage\&tqtf=false - consultado em 19/7/2010]

49

SILVA, Damião Goneto e [Tradutor]. Historia chronologica dos Papas, Emperadores, e Reys que tem reynado na Europa, do nascimento de Christo até o fim do anno 1730. Coimbra: na offic. de Antonio Simoes Ferreyra, 1731. p.XXXVII.

50

VERNEY, Luis Antonio. Verdadeiro Método de Estudar: para ser util à Republica, e à Igreja: proporcionado ao estilo, e necesidade de Portugal. Valensa [Nápoles]: na Oficina de Antonio Balle [Genaro e Vicenzo Muzio], 1746, t.2, p.290-291.

51

Directorio...0p. Cit., passim.

52

VIEIRA, Antonio. A Dictionary of the Portuguese and English Languages, in Two Parts, Portuguese and English: and English and Portuguese. Londres: Printed for J. Nourse, Bookseller to His Majesty, 1773, 1v., s.p. [consultado em GoogleBooks: http://books.google.com.br/books?id=MTZAAAAAY AAJctprintsec=frontcover - em 20/7/2010].

53

Ibidem, Vol.2, s.p. do campo, das aldeias, inicialmente não civil porque habitava fora do muro da cidade; do interiorano das pequenas vilas também aparte do mundo urbano; do cidadão de baixa condição, presente no espaço citadino mas aparte dele por sua condição vil. Campo, Vila, Cidade, espaços constitutivos do reino - mas separados da Corte; espaços dos atributos Camponês, Vilão, Cível - contrapostos a Cortesão; qualificativos esses sem Civilidade mas também sem Cortesia. A entrada "Villa", além de definir as características da povoação, referia-se a "Moça ou pessoa da villa, i.e., pouco polida, e urbana" ${ }^{47}$. Tais posições sociais (camponês, não nobre, habitante de povoação pequena) estavam associadas à ideia de rusticidade, descortesia, pouca polidez, falta de urbanidade. A entrada de Morais, assim, não diferenciava tanto da ambiguidade existente em Bluteau, apesar das ressalvas do novo e mais atualizado dicionário no verbete "civilidade".

Impresso seis anos antes, o dicionário organizado por Bernardo de Lima e Melo Bacellar, entretanto, não apontava o sentido negativo dos termos ligados a "civil" e indicava outras variantes que não constavam nem em Bluteau nem depois em Morais. Isto mesmo que o autor afirmasse (desde o título) estar se baseando (simplesmente "dobrando") os termos de Bluteau e dos dicionários anteriores, a fim de estabelecer uma "ortografia racional". Nesse esforço, reduzira tanto civel quanto civil ("CI-VEL, il") ao significado de "urbano", vindo de "civilis", listando uma série de derivados: civilmente, civilidade, civilíssimo, civilismo, civilizar, civilizado, apresentados, contudo, somente pelos seus sufixos. ${ }^{48}$ Para além da elisão da ambiguidade, chamo atenção para a aparição do verbo civilizar (sufixo -zar) e civilizado (-zado) derivados mais diretamente de civilidade (-ilidade, gerando a raiz civili-, implícita no verbete e ao que se complementariam -zar e -zado). 0 termo "civilizar" aparecera bem antes em fontes impressas distintas como: em um prefácio a uma tradução, de 1731, de história dos papas e reis, ao falar da ação positiva de um czar ao tentar introduzir a ciência em meio ao bárbaro povo russo ${ }^{49}$; em uma das cartas do Verdadeiro método de Verney, de 1746, ao tratar da necessidade da educação dos jovens ${ }^{50}$; e, profusa e recorrentemente, no Diretório dos Índios, ao falar como deveriam ser civilizados os índios do Maranhão ${ }^{51}$.

Civilizar e civilizado tinham aparecido também no dicionário bilíngue português-inglês de Antonio Vieira, de 1773. Civilizado remetia a civilizar, descrita como "(a new word) to civilize or make civil, to soften or polish manners. From the French civilizer". Vieira indicava ser um neologismo no português, derivado do francês. Contudo, Vieira, ao tratar de civil e civilidade apontava para sentidos depois classificados como antigos por Morais. Civil era aquilo pertencente à cidade mas remetia-se também aos verbertes "descortez", e no verbete "CIVEL", além de enviar para "Civil", mandava primeiro ver "rustico, camponez". Civilidade era simplesmente "descortezia, grosseria, rusticidade"52. Tanto assim que "Civility" era traduzido simplesmente como "cortezia", ainda que "rusticity" não remetesse à civilidade ${ }^{53}$. 0 neologismo "civilizar", advindo de um estrangeirismo, somava aos termos derivados de Civil o processo de polir e adquirir boas maneiras, mas seu significado mais corrente e próprio ao português, segundo o que se poderia depreender de Vieira, seria a rusticidade seja do camponês seja daquele vil que vivia na cidade.

O Novo diccionario das linguas portugueza, e franceza, com os termos latinos (1764), de José Marques, não trazia tantas entradas, reduzindo ainda mais os derivados de civil somente ao seu sentido de rústico ("civil", "ci- 
MARQUES, Joseph. Novo diccionario das linguas portugueza, e franceza, com os termos latinos. Tirado dos melhores authores, e do Vocabulario Portuguez, e Latino do P. D. Rafael Bluteau, dos Diccionarios da Academia Franceza, Universal de Trevoux, de Furetiere, de Tachard, de Richelet, de Danet, de Boyer, Etc. Lisboa: Na Officina Patriarca de Francisco Luiz Ameno, 1764, Vol.2, p.164, 633 752 [versão digital consultada em GoogleBooks: http://books.google.com.br/books?id=Fwsk_ oraZC4CEtprintsec=frontcover - em 20/7/2010].

\section{5}

FORBONNAIS, François Véron Duverger de. Elementos do commercio, traduzidos livremente do Francez para o Portuguez pelo mesmo traductor do Telemaco, e das Oraçoens funebres. Lisboa: A. Rodrigues Galhardo, 1766. p.199, grifo meu [versão digital consultada em The Making of the Modern World: <http://galenet.galegroup. com/servlet/MOME?af=RN\&tae=U101282167\&src htp $=$ actste $=14>-$ em 23/1/2011] .

56

COSTA E SÁ, Joaquim José da. Diccionario italiano e portuguez, extrahido dos melhores lexicografos, como de Antonini, de Veneroni, de Facciolati, de Franciosini, do Diccionario da Crusca e do da universidade de Turin (...) Lisboa: Na Regia Officina Typografica, 1773. p.311 [versão digital consulta em GoogleBooks: http://books.google. com.br/books?id=3ENAAAAAcAAJCtprintsec $=$ front cover - em 20/7/2010].

57

MORAES SILVA, Antonio de. Diccionario da lingua portugueza - recopilado dos vocabularios impressos ate agora, e nesta segunda edição novamente emendado e muito acrescentado, por Antonio de Moraes Silva. $2^{\text {a }}$ edição. Lisboa: Typographia Lacerdina, 1813 [Consultado no acervo on-line do Instituto de Estudos Brasileiros/ USP: http://www.ieb.usp.br/online/index.asp em 21/5/2010]; MORAIS SILVA, António de. Diccionario da lingua portugueza, recopilado de todos os impressos ate' o presente. 3. ed., mais cor. e accrescentada. Lisboa: Na typ. de M.P. de Lacerda, 1823 [Consultada em Internet Archives: http://www.archive.org/details/ diccionariodalin02morauoft - em 21/01/2011]. Sobre as diferenças entre as duas edições do dicionário feitas em vida, ver: MURAKAWA, Clotilde de Almeida Azevedo. Léxico e gramática no Diccionario da língua portuqueza (1813) de António de Morais Silva. Alfa, São Paulo, Vol.50, n.2, 2006, p.55-67.

58

MORAIS SILVA, Antonio de. Diccionario da Lingua Portugueza, composto por Antonio de Moraes Silva. 4a edição, Lisboa: Imp.Regia. 1831, Vol.1, p.395.

59

Para a história do termo em francês e em inglês, utilizei-me dos textos já citados de Lucièn Fèbvre, Émile Benveniste, Jean Starobinski, Bruce Mazlich, Brett Bowden, Pim den Boer, entre outros. Para a recorrência nos dicionários franceses, vali-me da base de dados do projeto ARTLF, Dictionaires d'atutrefois, que contém dicionários de 1606 ate 1935, pesquisando o termo "civilisation": http:// artflx.uchicago.edu/cgi-bin/dicos/pubdico1look. $\mathrm{pl}$ ?strippedhw=civilisation [consulta realizada no vel", "civilidade") e ao que concernia à vida na cidade ("cívico"). Ao traduzir para o francês "rústico" traduzira por "incivil", e "villanía" por "incivilité", mas não havia correspondência em português a essas acepções francesas de civil/civilidade..$^{54}$ É curioso notar que num dicionário que vertesse termos e expressões portuguesas para a língua da civilidade (e do civilizar, como lembrara Vieira) não constasse um sentido de cortesia. Mais do que isso, uma obra francesa traduzida para o português, impressa quase na mesma altura, trazia o termo "civilidade" nesta outra acepção como qualidade distintiva das repúblicas e cidades: "De todos os attractivos de hum Reino, ou de huma capital, o mais principal he a civilidade de um povo"55.

Mas mesmo entre os dicionários bilíngues não havia padrão. Num dicionário português e italiano (língua nem tão afeita ao termo civilidade), de 1773, civil e derivados só remetem ao sentido positivo. 0 adjetivo "Civile" é traduzido por "civil, cortezão, cortez, político (...) polido, razoavel, dotado de civilidade", mas também "fidalgo, bem nascido (...) de nobres costumes". 0 substantivo "Civiltá", "abstracto de civil", por "civilidade, policia, cortezia, urbanidade" ${ }^{56}$. Civilidade aqui novamente aparece junto à cortesia, urbanidade e polícia, antônimos de rusticidade.

Aparte dessa ambiguidade, os dicionários portugueses da segunda metade do séc. XVIII continuavam sem a entrada civilização, àquele momento um neologismo. Somente no século XIX, entraria lentamente para os repertórios lexicográficos. Por exemplo, sequer na segunda e terceiras edições do Morais Silva, de 1813 e 1823, revistas e ampliadas pelo autor, ela constava. Publicadas sem a menção direta no título ao Vocabulário de Bluteau, mantiveram a mesma entrada tanto para "civilidáde" quanto para "civil" somente na quarta edição, de 1831, portanto após a morte do dicionarista Antônio de Morais Silva, que se incluiu o termo "civilização" e o verbo "civilisar", ainda que persistisse a presença dos seus quase antônimos "civéldade" e "civel" 58 . Mas mesmo em francês e inglês (línguas nas quais pela primeira vez teria aparecido o termo) a palavra aparecera dicionarizada somente um par de anos antes da primeira edição de Morais de 1789.59

Em francês e inglês, como mostraram Lucien Febvre e Starobinski ${ }^{60}$, os termos civil e civilidade, empregados respectivamente desde o séc. XIII e XIV, cedo remeteram à polidez e aos bons modos. Civilidade aparecia no dicionário de Furetière (1690) como "Manière honnête, douce et polie d'agir, de converser ensemble"61. No século XVI, Montaigne teria usado o termo civilizado (do verbo civilizar) para definir os mexicanos como os mais engenhosos entre os povos americanos. ${ }^{62} 0$ termo civility apareceu ligado a boas maneiras ou ao modo cortês de se expressar e portar num dicionário inglês-latim de 1587, ao traduzir a palavra urbanitas. Ainda que não constasse como entrada nos dicionários ingleses até finais do séc. XVII, civilidade era termo recorrente para qualificar ou explicar vocábulos e expressões como "Urbanity", "Moral Philosophy", "Moral", "Comitie". Em 1668, em An Essay towards a Real Character and a Philosophical Language, de John Wilkins, a entrada "civility" foi sucintamente explicada como "Manners", talvez traduzindo a intenção da obra em criar uma linguagem comum de fácil uso para os letrados e diplomatas da Europa. ${ }^{63}$ Em suma, civilidade em inglês e francês desde o século XVI não indicava uma contraposição, como em Barbosa, Pereira e Bluteau (depois "corrigido" por Morais) entre a 
dia 20/5/2010]. Para as referências em dicionários, vocabulários e léxicos da língua inglesa até 1701, utilizei-me da base on-line Lexicons of Early Modern English, consultando os termos "civil", "civility" e "civilization": http://leme.library. utoronto.ca/ [consultas feitas em 21/5/2010]. Também utilizei-me do Oxford English Dictionary Online: http://dictionary.oed.com [consulta feita em 22/5/2010]. Além dessas bases voltadas para lexicografia e dicionários, pesquisei pelos termos em questão e correlatos em bases on-line de documentos e livros, entre outros: The Making of the Modern World: The Goldsmiths'-Kress Library of Economic Literature [http://galenet.galegroup. $\mathrm{com} /$ servlet/MOME?loclD=uspetste=23 - vários acessos]; a Eighteenth Century Collections Online [http://find.galegroup.com/ecco/start. do?ctprodld=ECCO - vários acessos]; o Google Books [http://books.google.com/ - vários acessos]; e Internet Archives [http://www.archive.org/ vários acessos].

60

FEBVRE, Lucien. Op. Cit.; STAROBINSKI, Jean. Op. Cit.

61

Apud. FEBVRE, Lucien. Op. Cit., p.22.

62

STAROBINSKI, Jean. Op. Cit., p.11.

63

Para as referências anteriores em inglês, busca pelo termo "civility" na base LEME: http://leme. library.utoronto.ca/ [consulta feita em 21/5/2010].

64

Dictionnaire universel françois et latin,

vulgairement appelé Dictionnaire de Trévoux: contenant la signification et la définition des mots de l'une et de l'autre langue... Paris: Compagnie des libraires associés, 1771 (T.2, BoulevartCrayonneux), p.617. [versão online consultada na Gallica: http://gallica.bnf.fr/ark:/12148/ bpt6k509819.r=trevoux+dictionnaire+1771. langPT - em 31/5/2010]

65

STAROBINSKI, Jean. Op. Cit., p.17-20; MAZLICH, Bruce. 0p. Cit., p.5-6.

66

Dictionnaire de Trévoux..., Op. Cit., p.617.

67

MAZLICH, Bruce. Op. Cit., p.6-7.

68

STAROBINSKI, Jean. Op. Cit., p.18. vida do povo que habita o campo (e por extensão o povo das cidades não polido) e as camadas cortesãs (ou corteses) que habitam o espaço urbano (porém em torno da corte), mas sim, aquilo que define o refinamento, a polidez, enfim o cultivo das boas maneiras (a cultura) próprias à urbanidade, ao espaço urbano. Apesar desse uso de civilidade não como ligado à vilania, rusticidade (como em português e castelhano), pelo contrário, como sinônimo de boas maneiras e urbanidade (ou seja, mais próximo ao sentido latino próprio da civilitas, da vida na civitas/pólis), civilização não era termo que existisse nos dicionários quinhentistas e seiscentistas, e mesmo nos setecentistas, até o último quartel do século. Aparecia, por vezes, num sentido jurídico, de tornar um processo criminal em civil.

A definição mais próxima à atual do termo apareceu em 1771 na última edição do Dictionnaire universel françois et latin, conhecido como Dicionário de Trévoux. Capitaneado pelos jesuítas, o Dicionário de Trévoux pretendia ser uma compilação e atualização quase enciclopédica de todos os dicionários da língua francesa, suprimindo, contudo, o que viam como a influência protestante e jansenista de outros dicionários franceses. 0 Dicionário de Trevoux definia assim o termo "civilisation":

CIVILISATION, s.f., terme de Jurisprudence. C'est un Acte de justice, un judgmente qui rend civil un procès criminel (...)

L'ami des hommes a employé ce mot pour sociabilité (...) La religion est sans contredit le premier \& plus utile frein de l'humanité: c'est le premier ressort de la civilisation. Elle nous prêche, \& nous rapelle sans cette la confraternité, adoucit notre coeur. ${ }^{64}$

A definição de civilisation continuava sendo a jurídica, mas os autores de Trevoux, em 1771, adendaram um sentido que havia aparecido, pela primeira vez na língua francesa, 12 anos antes no texto L'ami des hommes. 0 L'ami des hommes era um tratado escrito pelo Marquês de Mirabeau (1715-1789), pai do revolucionário Conde de Mirabeau, mas publicado anonimamente em 1756. 0 trecho que explica o termo ("La religion...") era uma citação retirada do livro, no qual a palavra civilização fora empregada mais duas vezes. Como observaram Bruce Mazlich e Jean Starobinski ${ }^{65}$, essa primeira aparição do termo, não sem certa ironia, está associada não a pressupostos de secularização e racionalidade, que identificamos às Luzes setecentistas, mas à necessidade da religião como freio da humanidade, para que nos civilizemos, adoçando os corações e nos confraternizando. No trecho escolhido pelos dicionaristas, a sociabilidade, i.e., o viver em sociedade, está ligada aos princípios do cristianismo, o que converge com o projeto de Trevoux. Algo que inclusive era reforçado pelo verbete "civiliser" que vinha logo abaixo e dizia que "La Prédication de l'Evangile a civilisé les peuples barbares les plus sauvages" 66 .

As outras duas aparições do termo no tratado de Mirabeau, se não contradizem a primeira, apontam para significados diversos, mostrando quais os caminhos para se evitar a bárbarie e a decadência por meio da civilização, da riqueza e da liberdade. ${ }^{67}$ Para Mazlich e Starobinski, esse início plurisemântico do termo permaneceu durante bastante tempo, dando ao conceito uma amplitude e variação que, em geral, não consideramos. Segundo Starobinski, para época, deveríamos pensar não em uma idéia de civilização, pois, de fato "existem as civilizações"68.

Na mesma altura do Dicionário de Trévoux, estava sendo redigido o Diccionario Castellano do também jesuita Esteban Terreros y Pando. Trazia 
69

FERNANDÉZ SEBASTIÁN, Javier. Op. Cit., p.86.

70

TERREROS Y PANDO, Esteban. Diccionario Castellano con las voces de ciencias y artes y sus correspondientes en las tres lengaus francesa latina e italiana. Madrid: En la imprenta de la viuda de Ibarra, Hijos y Companía, 1786, t.1, p.439-440 [versão online consultada na Biblioteca Foral de Bizkaia: http://bibliotecaforal. bizkaia.net/search*spi S5/a?a - em 04/11/2010].

71

cf. FERNANDÉZ SEBASTIÁN, Javier. Op. Cit.
72

ASH, John. The new and complete dictionary of the English language: To which is prefixed, a comprehensive grammar. Vol.1. Londres: Printed for Vernor and Hood, 1795. Não consegui consultar a primeira edição, portanto cito a partir da segunda. Contudo, na edição de 1775 já constava o termo e a definição, pois a citação da primeira edição está presente no Oxford English Dictionary, sob o verbete "civilization".

73

MORAIS SILVA, Antonio de. Diccionario da Lingua Portugueza, composto por Antonio de Moraes Silva.... Op. Cit., vol.1, p.395.

74

Para os dicionários da RAE, utilizei sua base de dados on-line (que cobre os dicionários impressos entre 1726 e 1992), pesquisando o termo "civilización": http://buscon.rae.es/ntlle/SrvltGU IMenuNtlle?cmd=LemaCtsec=1.6.0.0.0 [consulta realizada no dia $21 / 5 / 2010]$. tanto o significado em espanhol, em geral, com abonamentos ou exemplos de emprego, como a correspondência do termo em francês, latim e italiano. Impresso em 1786, estaria pronto desde 1765 - seis anos antes da publicação do Trévaux portanto ${ }^{69}$ - e trazia os dois sentidos para "civilización": "termino Forense, acto de justicia, que hace civil una causa criminal (...) tambien se puede decír por la accion de civilizár, y domesticar algunos pueblos silvestres: la civilizacion de los Brasileños fue mui dificil para los Misioneros. ${ }^{70}$. 0 sentido religioso e de cristianização dos gentios presente em Trévoux estava também destacado aqui, pois a ação de civilizar (e domesticar) tinha como objeto os povos silvestres ("les peuples barbares les plus sauvages" em Trévoux), dando como exemplo para abonar uma referência aos missionários no Brasil e seu trabalho junto aos "Brasileños". Assim, se aceitarmos a data de produção e não de impressão de Terreros y Pando ${ }^{71}$, as primeiras entradas dicionarizadas de civilização (junto a civilizar) tinham, de um lado, um acento religioso, no qual o cristianismo era um dos reguladores das paixões que permitia o ato de civilizar, e uma inflexão para o trabalho de conversão dos gentios, pois um dos sentidos da civilização era "domesticar" os povos selvagens, bárbaros e silvestres. Ao mesmo tempo, ao par dos novos significados dos termos civilização, civilizar, civilizado, o dicionário de Terreros y Pando trazia a mesma ambiguidade em relação a civil presente em Bluteau: "Civil, se tome en Castellano, fuera de esto, en dos sentidos contrarios (...) lo mismo que racional, humano, politico (...) y tambien se dice de un proceder civil, indigno, Etc..." Como abonação reproduz versos da comédia seiscentista do jesuíta Calleja, sobre a vida de Xavier, que termina dizendo sobre "mas CIVIL mujer", e conclui que em Espanha este sentido era o "mas comun, y usado", remetendo aos verbertes "Indigno, malo". Em "Civilidad" também permanece a dupla acepção do termo: por um lado, "Cortesía, Afabilidad, sociabilidád"; por outro, "mezquindád, ruindád". Interessante notar que em "civilización" (assim como na entrada do verbo "civilizar") a contraposição desaparece, e mais, ao ressaltar o processo, o ato (menos que o estado de civilidade com sua ambiguidade) o faz nem tanto ligado à cortesia/cortesania, mas sobretudo ao transformar o rústico gentio em civilizado.

Em 1775, num dicionário inglês escrito por John Ash, entretanto, constava somente o sentido de sociabilidade, e desaparecia a acepção jurídica (bem como o acento dado à religião e ao trabalho missionário). The new and complete dictionary of the English language dizia que civilização vinha do verbo "to civilize" e era: "the state of being civilized, the act of civilizing".72 Na quinta edição do Dictionnaire de l'Académie Française, impresso em 1798, a definição era praticamente a mesma, porém com os termos invertidos, dando ênfase à ação (ainda que sem a etimologia explícita do verbo civiliser): "CIVILISATION. sub. fém. Action de civiliser, ou état de ce qui est civilisé". É essa definição que vai se solidificar e se espalhar pelos dicionários na primeira metade do sec. XIX. Inclusive a entrada da quarta edição do dicionário de Morais (1831) era muito similar a do Dictionnaire, podendo sugerir o conhecimento e talvez a tradução a partir do dicionário da Academia Francesa: "CIVILISAÇÃO, s. f. 0 acto de civilisar: o estado do povo civilisado."73.

Em Trevóux, Terreros y Pando, Ash e no Dictionnaire, como depois no Diccionario de la lengua castellana da Real Academia Espanhola (RAE), de $1817^{74}$, e no Morais e Silva de 1831, a acepção de civilização não remetia portanto a uma entidade (uma Civilização) mas a um estado, de alguém 
75

"CIVILIZACION. s.f. Aquel grado de cultura que adquieren pueblos ó personas, cuando de la rudeza natural pasan al primor, elegancia e dulzura de voces, usos y costumbres proprios de gente culta. Urbanitas, civilitas, comitas". (grifos meus) É interessante notar que aqui o sentido da ação de civilizar desapareceu.

76

A relação de "barbare" com a incivilidade só aparecerá na edição de 1835 do dicionário da Academia Francesa.

77

JOHNSON, Samuel. A dictionary of the English language: in which the words are deduced from their originals, and illustrated in their different significations by examples from the best writers : to which are prefixed, a history of the language, and an English grammar. Londres: J. F. And C. Rivington [etc.], 1785. p.219, 278, 305 [versão online consultada em Internet Archives: http://www.archive.org/ stream/dictionaryofengl01johnuoft\#page/n219/ mode/1up/search/civil - em 21/5/2010].

78

"CIVILISATION. N.f. [from civil] A law, act of justice, or judgmente, which render a criminal process civil; which is performed by turning an information into an inquiet, or the contrary." Ibidem, p.386.

79

Samuel Johnson, segundo o diário de James Boswell, numa conversa registrada como sendo de 1772 e depois utilizada na biografia de Johnson escrita por Boswell, não admitia a palavra "civilization" como contrária à

"barbarity", somente "civility", pois, como outros termos, seria mais "legitimate English". Boswell, contudo, ainda que com grande deferência para seu interlocutor (e depois biografado), discordava de Johnson e achava que o termo "civilization" cabia melhor pois ligado ao verbo "to civilize". BOSWELL, James. The life of Samuel Johnson. Londres: J. Davis, 1817, Vol.1, p.311.

80

SHERIDAN, Thomas. A general dictionary of the English language. One main object of which, is, to establish a plain and permanent standard of pronunciation. To which is prefixed a rhetorical grammar. Londres: Printed for J. Dodsley, pall-mall C. Dilly, in the poultry, and J. Wilkie, St. Paul's church-yard, MDCCLXXX [1780], p. 1, grifos meus.

81

Para o Noah Webster's, utilizei o site Noah Webster's 1828 American Dictionary: http:// www.1828-dictionary.com/d/word/civilization (consulta feita em 22/5/2010).

82

Pesquisa no Dictionaires d'atutrefois, projeto ARTFL, em 3/6/10: http://artflx.uchicago.edu/cgibin/dicos/pubdico1look.pl?strippedhw=barbare. que é ou foi civilizado, ou a uma ação, a ação de civilizar. Ação esta que se traduzia, muitas vezes, no ato missionário, no trabalho de conversão do gentio. Não indicava uma nação, povo ou uma sociedade civilizada (acepção que aparecerá, por exemplo, somente no Dictionnaire de 1872, mas que está já no verbete de 1822 do Diccionário da RAE ${ }^{75}$ ), mas sim 0 ato de tornar alguém civil, de dar civilidade a alguém que não a tivesse (em suma, aqueles que eram caracterizados pela selvageria e barbarismo ou rusticidade e grosseria - segundo Bluteau no verbete invertido). Civilização era retirar alguém de um estado de falta de urbanidade, de polidez, de cultura. Quem era esse alguém?

$* * *$

Segundo a sexta edição do dicionário de Samuel Johnson (1785), bárbaro era aquele "man uncivilized; untaught; a sauvage"76, definição quase idêntica aos adjetivos "brutish" (como um bruto, como uma fera) e "boorish", este referente a pessoas do campo. ${ }^{77} \mathrm{Em}$ Samuel Johnson, não ser civilizado era atributo do selvagem, daqueles próximos aos animais, às feras, ou então dos que viviam no campo. E civilidade (civility) era primeiro "Freedom from Barbarity; the state of being civilized", para depois ser atributo da polidez. A entrada "Civilization" constava no dicionário, mas permanecia referente a transformar um processo criminal em civel ${ }^{78}$, campo semântico (o jurídico) que se imiscuia ao ligado à noção de respublica (sentido público e sociedade, ao mesmo tempo) nos vocábulos derivados dos termos latinos cives, civitas e civilitas. Johnson não achava que "civilization" (na acepção de civilizar) funcionasse como contrário a bárbarie, preferindo o mais recorrente "civility"79.

Impresso em 1780, A General Dictionary of the English Language, de Thomas Sheridan, definia "civility" e "barbarian" nos mesmos termos de Johnson. Embora não contivesse a entrada "civilization" nem na acepção jurídica citada, no prefácio de Sheridan aparecia o termo usado na acepção mesmo de civilizar e ligado à polidez e ao cultivar a língua - por meio, inclusive, quem sabe, de se produzir dicionários:

Whilst the ingenious natives of other countries in Europe, particularly the Italians, French, and Spaniards, in proportion to their progress in civilization and politeness, have for more than a century been employed, with the utmost industry, in cultivating and regulating their speech, we still remain in the state of all barbarous countries in that respect, having left our's wholly to chance. ${ }^{80}$

Quatro décadas depois, na primeira edição do dicionário de Noah Webster (1828), o vocábulo "civilization" constava novamente, depois de um hiato de quatro décadas nos dicionários ingleses pesquisados. Era definido como "act of civilizing, or the state of being civilized" (mais próximo aos dicionários francês, espanhol e português do que o de Ash), mas adicionava a essa acepção o sujeito ser retirado de "the grossness of savage life and improved in arts and learning" ${ }^{81}$, reforçando a oposição ao estado selvagem e bárbaro. É interessante notar que, em geral, "barbare" nos dicionários franceses do séc. XVIII aparecia definido pela falta de polidez e de lei, mas não pela falta de civilidade, como nos ingleses. ${ }^{82}$ Starobinski observou como a noção de polidez (politesse) sobrepôs-se aos conceitos de civilização e civilidade, ao longo do sec. XVIII na França, como 
83

STAROBINSKI, Jean. "A palavra 'civilização'...", Op. Cit., p. 27-31.

84

S. LUIZ, Francisco de. Ensaio sobre alguns synonymos da língua portugueza por D. Fr.

Francisco de s. Luiz, sócio effectivo da Academia Real das Sciências, Etc, Ctc. $2^{\text {a }}$ ed. Lisboa: na Typografia da Academia R. das Sciencias, 1824 Vol.1, p.IV.

85

lbidem, p.178.
ELIAS, Norbert. Escritos e ensaios. Vol.1. Estado, processo, opinião pública. Rio de Janeiro: Jorge Zahar Editor, 2006. p.20-21. nivel distintivo acima do estar ou ser civil. Indicava que para aqueles que não tivessem a polidez necessária, a polícia, o policiar-se (homófona de politesse, mas não de mesma raiz) seria necessária como meio civil, portanto da política (de raiz comum), para civilizar e pertencer àquela civilização ou civitas/pólis ${ }^{83}$. Assim, segundo os dicionários franceses setecentistas, ao bárbaro, faltava tanto a polidez quanto a lei (i.e., a política, a vida na pólis), requisitos necessários para ser civilizado.

Esta evolução e relação entre civilização-polícia-polidez foi explicitada em português no Ensaio sobre alguns synonymos da língua portugueza, de 1824. Impresso pela Academia Real de Ciências de Lisboa, a partir de uma encomenda datada de 1812, o sócio Fr. Francisco de S. Luiz pretendia suprir uma lacuna na língua portuguesa, que contava, segundo ele, com poucos e incompletos dicionários. Particularmente, na questão dos sinônimos o português sofria com a imprecisão dos dicionários e de seus autores, em especial do "compilador de Bluteau", Morais e Silva. ${ }^{84}$ Dizia que era preciso diferenciar os termos similares, com precisão e acuidade filosófica, e não, tautologicamente, remeter um verbete ao outro, aquele termo a este, e este àquele.

Preocupado com isso, na entrada "Civilizado - Policiado - Polido", Fr. S. Luiz afirmava:
Hum povo he civilizado, quando tem deixado os costumes barbaros; quando se governa por leis. He policiado, quando, pela obediencia ás leis, tem adquirido o habito das virtudes sociaes. E he polido quando em suas acções mostra urbanidade, elegancia, e apurado gosto. (...) As leis estabelecem a civilização entre os povos barbaros, formando os bons costumes. Os bons costumes aperfeiçoao as leis, e algumas vezes as supprem, entre os povos policiados. A polidez exprime no trato e acções a perfeição das virtudes sociaes: e quando he falsa, como muitas vezes acontece, contenta-se de fingir e affectar essas virtudes. ${ }^{85}$

Aqui, civilização, que àquela altura ainda não estava dicionarizada em português, não era mais o estágio desejado de urbanidade (a civilidade de Morais) mas o inicial, linha divisória dos costumes bárbaros e de uma sociedade que tem leis. 0 policiamento dos povos, que resulta da obediência às leis mas a supera, cria as virtudes sociais, internalizando a coerção e os freios que pela lei eram aplicados. Essas virtudes quando refinadas pela elegância e bom gosto - mas também pelo luxo - transformam-se em polidez, alcançado (ou simulando, quando fingidas) a urbanidade de fato. A civilização, como processo, fica no primeiro degrau do policiamento e da polidez, e a civilidade traduz-se no sinônimo urbanidade nesse Ensaio de 1824, que adicionou patamares mais distantes entre o "bárbaro" e "civilizado".

0 substantivo Civilização referia-se, sobremaneira, a um ato, que pode resultar em um estado. Norbert Elias já havia chamado a atenção para o fato de que esquecemos, no uso cotidiano, que civilização é, originalmente, um processo menos do que uma entidade, frisando sua relação com o verbo civilizar. ${ }^{86}$ Nas acepções dicionarizadas do séc. XVIII, entretanto, seria um agir para com aqueles que não tinham atingido o estado de civilidade, urbanidade, elegância e cultura. Implicava uma relação entre o civilizado (leitor provável dos dicionários em questão) e aquele rústico, sem modos, inculto, ou aquele que é selvagem. Ao mesmo tempo, pressupunha 
87

STAROBINSKI, Jean. Op. Cit., p.16.

88

Ibidem, p.18

Recebido para publicação em agosto de 2011

Aprovado em dezembro de 2011

assim uma possibilidade de progresso, dado num telos, da incivilidade ou selvageria e barbárie para a urbanidade e polidez, estados supostamente desejáveis e finais do ser humano. ${ }^{87} \mathrm{E}$, se inicialmente o fazer-se e estar civilizado está ligado sobretudo ao espaço interno da sociedade, i.e., no âmbito de clivagem entre aqueles, daquela cidade ou daquela república que são civilizados e os que estão fora ou no limite do muro da cidade (no sentido inverso do de Bluteau, mas com a mesma dicotomia antiga), aos poucos os sujeitos da ação (o civilizador e o a ser civilizado) tornam-se povos, nações, culturas, dando esteio para a acepção mais atual e substantivada de Civilização $0^{88}$ - e que reforçava a antinomia presente nos dicionários (sobretudo de língua inglesa) entre civilizado e bárbaro/selvagem.

Em português, ao longo do séc. XVIII, civilidade, aos poucos, deixa de aparecer como um possivel sinônimo de rusticidade pois ligado à vida civil (isto é, não nobre e cortesã), e passa a indicar o estado no qual devem chegar os jovens e as nações europeias, mas também os selvagens brasileiros. Contudo, entre esses dois sentidos opostos estabelece-se uma tensão, que pode indicar dois eixos de atuação (e mudança) nas dinâmicas sociais, que levanto a título de hipóteses na conclusão deste texto.

Por um lado, a acepção negativa de civil e civilidade se volta para os âmbitos das relações no interior do reino, das cidades principais (e do campo e suas vilas), apontando as tensões internas na sociedade portuguesa entre as camadas e categorias sociais que compunham a estrutura do Antigo Regime. 0 viver urbano e cortesão era diferente do civil. Polidez era permitida ao gentil-homem, cortesão, educado, refinado, não a qualquer habitante da cidade. Mesmo que todos estivessem sob as mesmas Leis da polícia (governo e administração política), ter polícia (bons modos, razão) poucos (e bons) alcançavam. A contraposição civilidade/urbanidade significava explicitar no léxico a hierarquia do corpo da "civitas". Com o predomínio do emprego em uma outra acepção (refletindo talvez mudanças nessa divisão social), auxiliado pelo estabelecimento de uma ortografia uniforme no fim do sec. XVIII, dicionarizar como "civel" e "civéldade" pode ter sido um meio de explicitar uma distinção existente mas que precisava encontrar uma outra forma de ser grafada (ou mesmo de ser vivida).

Por outro, civilizar e, mais tarde, civilização aparecem, sem ambiguidades ou duplos sentidos, no esforço de educar os povos e retirá-los não só de seu estado rústico, mas também bárbaro e, sobretudo, selvagem. Não é à toa que um dos textos, afora os dicionários, no qual identifiquei de modo recorrente o emprego foi o Diretório, voltado para civilizar e cuidar da civilidade dos selvagens e bárbaros índios desregrados e sem polícia do Pará e Maranhão. 0 fato de civilização aparecer nos dicionários de Trévoux e de Terreros y Pando referentes ao trabalho missionário com os índios (e especificamente no Brasil, no segundo) não deixa de reforçar essa hipótese. Talvez civilizar fosse entendido mais como um ato inscrito na missão do Império Português em tirar os índios do estado de selvageria (e com isso garantir o tamanho de seus domínios), do que educar e polir as rústicas e vis gentes de seus campos, vilas e aldeias. Civilizar era uma dimensão para manter o Império, retirando o selvagem do seu estado bárbaro e tornando-o subjugado ao poder soberano das Leis da Cidade, mas a civilidade (em ambos sentidos) - e depois a polidez - servia para distinguir quem verdadeiramente era civilizado no interior dessa Cidade. 